\title{
FOXA1 Gene
}

National Cancer Institute

\section{Source}

National Cancer Institute. FOXA1 Gene. NCI Thesaurus. Code C101646.

This gene plays a role in the modulation of gene expression. 